\title{
HER-2 inhibition in gastric and colorectal cancers: tangible achievements, novel acquisitions and future perspectives
}

\author{
Valentina Fanotto ${ }^{1, *}$, Elena Ongaro ${ }^{1, *}, K^{2}$ arim Rihawi², Antonio Avallone ${ }^{3}$, Nicola \\ Silvestris ${ }^{4}$, Lorenzo Fornaro ${ }^{5}$, Enrico Vasile $^{5}$, Lorenzo Antonuzzo ${ }^{6}$, Francesco \\ Leone$^{7}$, Gerardo Rosati ${ }^{8}$, Francesco Giuliani', Roberto Bordonaro9, Mario \\ Scartozzi ${ }^{10}$, Giovanna De Maglio ${ }^{11}$, Francesca V. Negri ${ }^{12}$, Gianpiero Fasola ${ }^{1}$ and \\ Giuseppe Aprile ${ }^{1}$ \\ 1 Department of Oncology, University and General Hospital, Udine, Italy \\ 2 Department of Oncology, S.Orsola-Malpighi Hospital, Bologna, Italy \\ ${ }^{3}$ Gastrointestinal Medical Oncology Unit, National Cancer Institute "Fondazione Giovanni Pascale" -IRCCS, Napoli, Italy \\ 4 Department of Oncology, National CancerInstitute "Giovanni Paolo II" -IRCSS, Bari, Italy \\ ${ }^{5}$ Unit of Oncology 2, Azienda Ospedaliero-Universitaria Pisana, Pisa, Italy \\ ${ }^{6}$ Department of Oncology, Careggi Hospital, Firenze, Italy \\ 7 Department of Medical Oncology, University of Torino, Candiolo Cancer Institute-FPO-IRCCS, Torino, Italy \\ ${ }^{8}$ Medical Oncology Unit, San Carlo Hospital, Potenza, Italy \\ 9 Department of Oncology, ARNAS Garibaldi, Catania, Italy \\ 10 Department of Oncology, University Hospital, Cagliari, Italy \\ ${ }^{11}$ Department of Pathology, University and General Hospital, Udine, Italy \\ 12 Medical Oncology Unit, University Hospital, Parma, Italy \\ * These authors have contributed equally to this work \\ Correspondence to: Giuseppe Aprile, email: aprile.giuseppe@aoud.sanita.fvg.it \\ Keywords: gastric cancer, colorectal cancer, HER2-inhibition, prognosis, predictive factor \\ Received: December 11,2015 Accepted: June 16, $2016 \quad$ Published: August 12, 2016
}

\section{ABSTRACT}

HER-2 (ErbB-2, c-erbB2 or Her2/neu), a member of the HER-family, is directly involved in the pathogenesis and progression of several human cancers; as such, it is also often considered as a poor prognostic factor. Following the revolutionary impact of anti-HER-2 therapy in breast cancer patients, the role of HER-2 and its blockade has also been extensively evaluated in other tumor types, including gastric and colorectal adenocarcinoma. The aims of this review are to recall the important results achieved with the use of HER-2 inhibitors in both gastric and colorectal cancer, and to discuss on the updates available on the role of HER-2 as prognostic and predictive factor in these malignancies.

\section{INTRODUCTION}

HER-2 (ErbB-2, c-erbB2 or Her2/neu), a member of the HER-family that also includes HER-1 (Epidermal Growth Factor Receptor-EGFR, or ErbB1), HER-3 (ErbB3) and HER-4 (ErbB4), is a proto-oncogene that encodes for a 185-kDa plasma membrane-bound tyrosine kinase receptor, located on the chromosome 17 at q21 [1]. Its stimulation by extracellular signals leads to the activation of downstream pathways such as mitogen- activated protein kinase (MAPK), phosphoinositide3-kinase (PI3K), phospholipase $\mathrm{C}$ and protein kinase $\mathrm{C}$, inducing signal transduction and transcription [2, 3]. As such, HER-2 gene amplification and protein overexpression are involved in the pathogenesis and progression of several human cancers, thus they are often considered as a poor prognostic factor [4-6]. HER-2/ neu overexpression has been reported in many epithelial malignancies including lung, prostate, bladder, pancreatic cancer and osteosarcoma. But it is mainly due to the 
revolutionary impact of anti-HER-2 therapy in breast cancer patients that the role of HER-2 and its blockade has been evaluated also in other tumor types, including gastric and colorectal cancers (CRC). Although several targeted agents have been tested in randomized trials [7, 8], only trastuzumab in HER2-positive patients [9] and ramucirumab in an unselected population [10, 11] are currently approved in gastric cancer. Similarly to gastric cancer, also CRC is a highly heterogeneous disease [1214]. In such novel and more complex scenario, a better definition of HER-2 function in CRC has been achieved suggesting its involvement in disease pathogenesis as well as in the emergence of resistance to target therapy [15, 16]: as a result, HER-2 has been regarded as a potential therapeutic target.
The aims of this review are to recall the important results achieved with the use of HER-2 inhibitors in gastric and gastroesophageal junction cancers (as illustrated in Figure 1), and to discuss the updates on the role of HER-2 as prognostic and predictive factor in gastric and colorectal carcinomas.

\section{HER-2 AS A KEY TARGET IN GASTRIC CANCERS AND GASTROESOPHAGEAL JUNCTION CARCINOMAS}

Gastric cancer is a worldwide health problem, causing approximately one million deaths per year and ranking as the third leading cause of cancer-related deaths $[17,18]$. Although the role of HER-2 in this tumor has

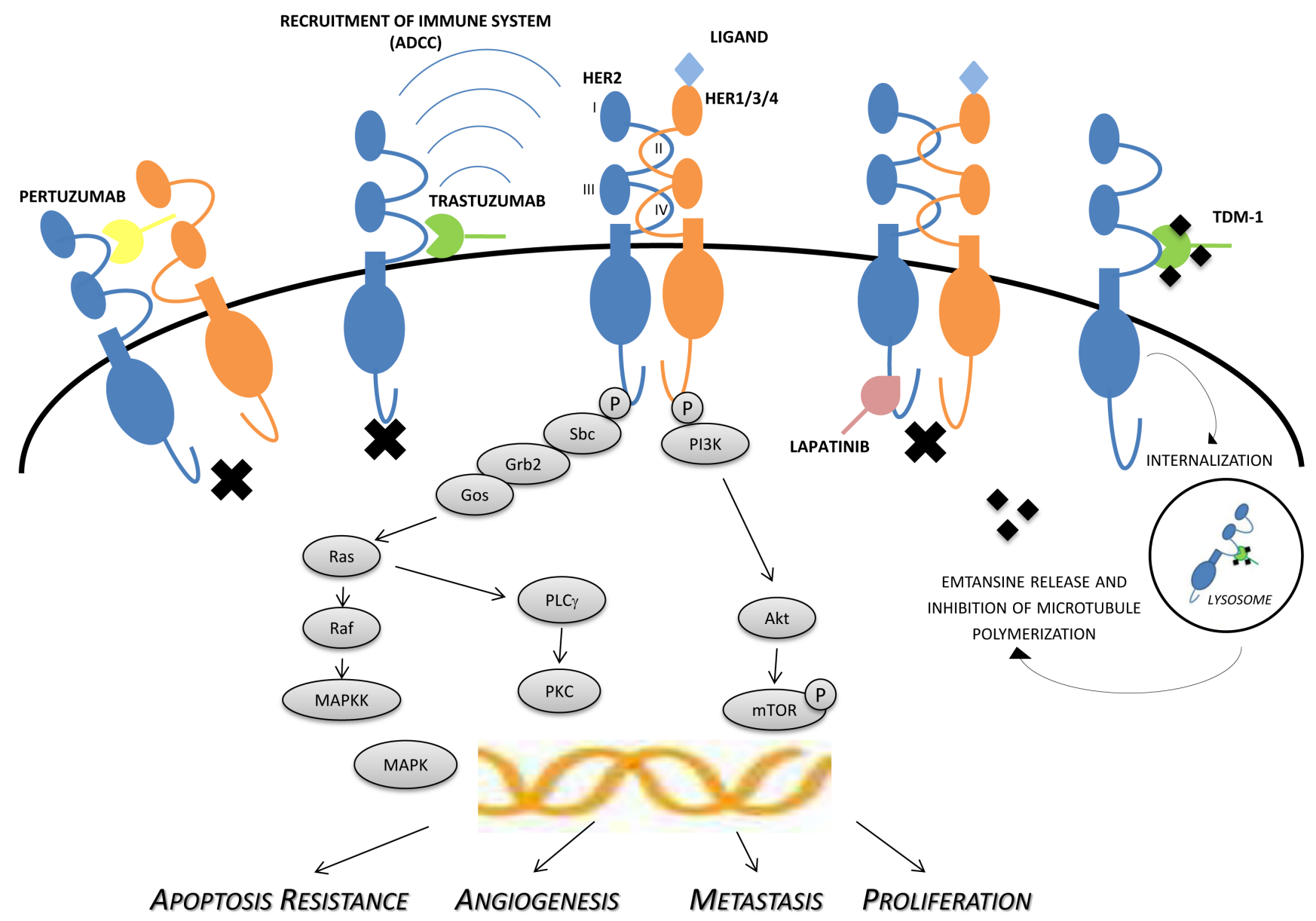

Figure 1: Mechanisms of actions of HER-2 inhibitors. The figure shows the complex crosstalk between members of the HERfamily and intracellular signaling, involved in proliferation, growth, invasion/metastases and angiogenesis. Activation of receptor kinase function occurs predominantly via ligand-mediated hetero- or homo-dimerization. In the case of HER-2, activation is also thought to occur in a ligand-independent manner, particularly when the receptor is found to be mutated or overexpressed. Trastuzumab is directed against the extracellular domain (IV) of HER-2, while pertuzumab binds to the extracellular dimerization domain (subdomain II). Immunologic mechanisms may also be involved in antitumor activity of trastuzumab, pertuzumab, and TDM-1, including ADCC. The potent smallmolecule lapatinib inhibits the tyrosine kinases associated with HER-1 and HER-2, resulting in inhibition of phosphorylation and downstream signaling. ADCC: antibody-dependent cell-mediated cytotoxicity, HER: human epidermal growth factor receptor, MAPK: mitogen-activated protein kinase, MAPKK: mitogen-activated protein kinase kinase, mTOR: mammalian target of rapamycin, P: phosphate group, PI3K: phosphatidylinositol 3-kinase, PKC: protein kinase C, PLC $\gamma$ : phospholipase C-gamma, TDM-1: trastuzumab emtansine. 
Table 1: Currently used HER-2 immunohistochemistry scoring system in gastric cancer depends on the available specimen.

\begin{tabular}{|l|l|l|l|}
\hline $\begin{array}{l}\text { SCORE } \\
\text { TO } \\
\text { REPORT }\end{array}$ & $\begin{array}{l}\text { HER-2 RECEPTOR } \\
\text { OVEREXPRESSION } \\
\text { ASSESSMENT }\end{array}$ & $\begin{array}{l}\text { SCORING PATTERN: } \\
\text { SURGICAL SPECIMEN }\end{array}$ & $\begin{array}{c}\text { SCORING PATTERN: } \\
\text { SMALL ENDOSCOPIC BIOPSIES } \\
\text { (AT LEAST 6-8 DIAGNOSTIC } \\
\text { FRAGMENTS) }\end{array}$ \\
\hline $\mathbf{0}$ & Negative & $\begin{array}{l}\text { No reactivity or membranous } \\
\text { reactivity in }<10 \% \text { of tumor cells }\end{array}$ & No reactivity in any tumor cell \\
\hline $\mathbf{1 +}$ & Negative & $\begin{array}{l}\text { Faint/barely perceptible incomplete } \\
\text { membranous reactivity in } \geq 10 \% \text { of } \\
\text { tumor cells }\end{array}$ & $\begin{array}{l}\text { Tumor cell cluster with a faint/barely } \\
\text { perceptible incomplete membranous reactivity } \\
\text { irrespective of percentage of tumor cells } \\
\text { stained }\end{array}$ \\
\hline $\mathbf{2 +}$ & Equivocal & $\begin{array}{l}\text { Weak to moderate complete, } \\
\text { basolateral or lateral membranous } \\
\text { reactivity in } \geq 10 \% \text { of tumor cells }\end{array}$ & $\begin{array}{l}\text { Tumor cell cluster with a weak to moderate } \\
\text { complete, basolateral or lateral membranous } \\
\text { reactivity irrespective of percentage of tumor } \\
\text { cells stained }\end{array}$ \\
\hline $3+$ & Positive & $\begin{array}{l}\text { Strong complete, basolateral } \\
\text { lateral membranous reactivity in in } \\
\geq 10 \% \text { of tumorcells }\end{array}$ & $\begin{array}{l}\text { Tumor cell cluster with a strong complete, } \\
\text { basolateral or lateral membranous reactivity } \\
\text { irrespective of percentage of tumor cells } \\
\text { stained }\end{array}$ \\
\hline
\end{tabular}

HER-2: human epidermal growth factor receptor 2.

already been extensively investigated [19], and found to be frequently associated with invasion, high grade, and unfavorable prognosis, its overall prognostic role remains controversial [20-24] and appears to be stage-dependent.

HER-2 positivity in gastric cancer is usually established with immunohistochemistry (IHC) and further confirmed with in situ hybridization (ISH) methods. Currently, tumor scoring slightly diverges between small endoscopic biopsies and surgical specimens (see Table 1 for details). ISH analysis, either with fluorescence in situ hybridization (FISH) or chromogenic in situ hybridization (CISH), is required for tumors with an IHC score $2+$ for which further assessments are needed to define the HER2 status $[25,26]$. Of note, HER-2 positivity may vary depending on the primary tumor location as well as the histology of gastric cancer. As a matter of fact, HER-2 overexpression/amplification is detected in more than $30 \%$ of the tumors arising from the gastroesophageal junction whereas less than $20 \%$ of the tumors arising from the gastric body are HER2-positive. Likewise, intestinal histology and diffuse histotype display a rate of HER-2 positivity of $34 \%$ and $6 \%$, respectively [27]. The Cancer Genome Atlas project has identified four subtypes of gastric cancer based on their different molecular biology, which could actually explain such variability in HER-2 expression [28].

The relevant biological role played by HER-2 eventually led to explore its potential as a therapeutic target. ToGA, a large international randomized phase III study, investigated the efficacy and safety of adding trastuzumab to combination chemotherapy of a fluoropyrimidine (capecitabine or 5-FU) plus cisplatin for the upfront treatment of HER2-positive advanced gastric cancer patients [9]. The study enrolled 594 patients in 24 countries. This practice-changing study showed that the addition of trastuzumab to backbone chemotherapy significantly prolonged the median overall survival (OS) compared with chemotherapy alone (13.8 months vs. 11.1 months, HR $0.74,95 \%$ CI $0.60-0.91$ ); of note, a post-hoc analysis showed that the overall survival gain was even greater $(+4.2$ months, HR 0.65$)$ for patients with higher HER-2 expression, i.e., IHC HER-2 3+ score or IHC HER-2 2+ score and amplified FISH (16.0 months vs. 11.8 months, HR 0.65 , 95\%CI $0.51-0.83$ ) [9]. Full screening results from the ToGA study have been recently reported, including data on IHC and FISH testing. A total of 3,803 patients were screened for HER2 status; either IHC or FISH testing was successful in 3,665 patients. Concordance between the two methods was $87.2 \%$; HER-2 overexpression/amplification rates were similar for European and Asian patients, but slightly lower for American patients. As previously reported, HER-2 overexpression or amplification was more common in patients with intestinal histology compared with those with diffuse histology $(31.8 \% v s$. $6.1 \%$ ) and in gastroesophageal junction cancer than in gastric cancer (32.2\% vs. 21.4\%), suggesting a different etiology and pathogenesis between proximal and distal gastric cancers [29]. However, a critical factor for the selection of potential responders to a trastuzumab-based 
therapy remains the intratumoral heterogeneity of HER2 amplification [30,31] which, together with a lack of uniformity and reproducibility of the criteria used for defining HER-2 positivity, could be responsible for the variable incidence rates reported in literature [32]. Following the positive results of ToGA trial, further investigations have been conducted in order to: a) define the optimal dose of trastuzumab in combination with chemotherapy; b) extend the addition of trastuzumab to other disease settings (i.e. preoperative or perioperative) and c) test the efficacy of novel HER-2 inhibitors either alone or in combination with trastuzumab.

The identification of the most appropriate dose of trastuzumab in addition to chemotherapy is currently being pursued within the HELOISE trial, a randomized phase III study, which compares two different dosing regimens (loading dose of $8 \mathrm{mg} / \mathrm{kg}$ followed by either $6 \mathrm{mg} / \mathrm{kg}$ or 10 $\mathrm{mg} / \mathrm{kg}$ of trastuzumab given every 3 weeks) in association with cisplatin/capecitabine chemotherapy, as first-line therapy in patients with HER2-positive metastatic gastric or gastro-esophageal junction adenocarcinoma. Primary study endpoints are safety and tolerability of an alternative trastuzumab dosing regimen based on a post-hoc analysis of ToGA trial [33]. In this trial, eligible patients have poor prognostic factors as ECOG performance status 2, primary tumor in site and metastatic involvement of at least two organs. In ToGA trial, trastuzumab was administered with an initial loading dose of $8 \mathrm{mg} / \mathrm{kg}$ followed by a maintenance dose of $6 \mathrm{mg} / \mathrm{kg}$ every 3 weeks. A total of 1,419 serum concentrations from 266 patients had a non-linear two-compartment pharmacokinetics (PK) with parallel linear and non-linear elimination. The nonlinear elimination pathway of trastuzumab is believed to represent a target-mediated clearance process associated with the binding to the extracellular domain of the HER-2 protein. For the dosing regimen investigated in the study, the non-linear pathway was not saturated continuously, leading to a change in the overall trastuzumab clearance between consecutive infusions. Based on the predicted concentrations, the total clearance was stable within the first 3 days but increases by $48 \%$ as concentrations decline. A post-hoc Kaplan Meier survival analysis was conducted with patients stratified according to quartile of trastuzumab trough concentration in treatment at cycle 1 . A significant difference in survival was observed according to quartile of trough trastuzumab concentrations in cycle 1 ( $\mathrm{p}<0.0001)$. Median survival time for patients within the lowest quartile of concentrations was 7.7 months $(95 \%$ CI 6.3-10.6 months), which was 7 to 10 months shorter than median survival time reported for patients with trough concentrations within other quartiles [34]. Whether the addition of trastuzumab is beneficial also in settings other than metastatic has also been investigated in a number of studies which, as a matter of fact, have already shown favorable outcomes of trastuzumab-containing perioperative chemotherapy. In the explorative HERFLOT phase II study, the activity of trastuzumab in addition to perioperative FLOT (5-FU, leucovorin, oxaliplatin and docetaxel) is being evaluated. The primary study endpoint is the rate of pathological complete response (pCR) evaluated by a central reference pathologist. Preliminary data presented on an interim analysis revealed no unexpected safety issues and a pCR achieved in more than $20 \%$ patients. Final results are awaited later this year [35]. Similarly, the PETRARCA phase II/ III trial of the AIO Group is evaluating the addition of trastuzumab and pertuzumab to FLOT vs FLOT alone in perioperative setting [36]. Moreover, the INNOVATION phase II study is assessing the activity of trastuzumab or trastuzumab plus pertuzumab in addition to perioperative standard chemotherapy [37]. In the TOXAG phase II trial, safety and tolerability of oxaliplatin, capecitabine and trastuzumab combination and radiotherapy as adjuvant therapy in surgically resected HER2-positive gastric or gastroesophageal junction cancer are being evaluated [38]. Finally, RTOG 1010 phase III is enrolling patients with esophageal HER2-positive adenocarcinoma in order to establish the efficacy of adding trastuzumab to chemoradiation [39].

Meanwhile, novel HER-2 inhibitors are also being studied in gastric cancer: lapatinib ditosylate, a dual antiEGFR and anti-HER-2 tyrosine kinase inhibitor, was firstly tested in the TRIO-013/LOGiC trial designed to evaluate the efficacy and safety of the oral inhibitor in combination with capecitabine and oxaliplatin as firstline treatment of advanced or metastatic HER2-positive esophagogastric cancer. In this study, 545 patients were randomized 1:1 to receive CAPOX q21 (oxaliplatin 130 $\mathrm{mg} / \mathrm{sqm}$, day 1 , capecitabine $850 \mathrm{mg} / \mathrm{sqm} /$ bid days 1-14) plus lapatinib (1,250 mg daily given continuously) or placebo. The primary endpoint was not met with an HR for OS of $0.91(95 \%$ CI $0.73-1.12 ; p=0.35)$, and a median OS of 12.2 months for standard treatment vs. 10.5 months in the experimental arm. Median progression-free survival (PFS) was 6.0 months (95\% CI, 5.6 to 7.0$)$ in experimental arm and 5.4 months (95\% CI, 4.4 to 5.7$)$ in control arm with an HR of 0.82 (95\% CI,0.68-1.00; $p=0.0381)$. Overall Response Rate (ORR) was 53\% (95\% CI, 46.4$58.8)$ in the experimental arm and $39 \%$ (95\% CI, 32.9$45.3, p=0.0031)$ in the placebo arm [40]. In the openlabel, phase III TyTAN trial, 261 HER2-positive advanced gastric cancer Asian patients were randomized to receive weekly paclitaxel with or without lapatinib, as secondline treatment. Once again, no benefit was demonstrated in terms of OS (HR 0.84, 95\% CI 0.64-1.11; $p=0.10$ ) or PFS (HR 0.85, 95\%CI 0.63-1.13; $p=0.24$ ) for the use of lapatinib, though a statistically significant improvement in RR was noted $(27 \%$ v 9\%, OR $3.85,95 \%$ CI $1.80-8.87 ; p$ $=0.001)$ [41].

Possible reasons for these negative results are the high proportion of patients with IHC HER-2 1+ score, which might have diluted the benefit of lapatinib in patients 
Table 2: Principal results with HER-2 inhibitors in advanced HER2-positive gastric cancer.

\begin{tabular}{|c|c|c|c|c|c|c|c|c|}
\hline \multirow[t]{2}{*}{ TRIAL } & \multicolumn{2}{|l|}{ REGIMEN } & \multirow[t]{2}{*}{ PHASE } & \multirow[t]{2}{*}{ LINE } & \multirow[t]{2}{*}{$\begin{array}{l}\text { PRIMARY } \\
\text { ENDPOINT } \\
\end{array}$} & \multirow[t]{2}{*}{ ORR (\%) } & \multirow[t]{2}{*}{$\begin{array}{l}\text { PFS } \\
\text { (months) }\end{array}$} & \multirow[t]{2}{*}{$\begin{array}{l}\text { OS } \\
\text { (months) }\end{array}$} \\
\hline & $\begin{array}{l}\text { Experimental } \\
\text { Arm }\end{array}$ & Control Arm & & & & & & \\
\hline $\begin{array}{l}\text { ToGA } \\
\text { NCT01041404 }\end{array}$ & $\begin{array}{l}\text { Capecitabine } \\
\text { or iv 5-FU } \\
+ \\
\text { Cisplatin } \\
+ \\
\text { Trastuzumab }\end{array}$ & $\begin{array}{l}\text { Capecitabine } \\
\text { or iv 5-FU } \\
+ \\
\text { Cisplatin }\end{array}$ & III & I & OS & $\begin{array}{l}47.3 \text { vs. } 34.5 \\
\mathrm{OR}=1.70 \\
95 \% \mathrm{CI} \\
1.22-2.38 \\
p=0.0017\end{array}$ & $\begin{array}{l}6.7 \text { vs. } 5.5 \\
\mathrm{HR}=0.71 \\
95 \% \mathrm{CI} \\
0.59-0.85 \\
p=0.0002\end{array}$ & $\begin{array}{l}13.8 \quad v s . \\
11.1 \\
\mathrm{HR}=0.74 \\
95 \% \text { CI } \\
0.60-0.91 \\
p=0.0046\end{array}$ \\
\hline $\begin{array}{l}\text { LOGiC } \\
\text { NCT00680901 }\end{array}$ & $\begin{array}{l}\text { Capecitabine }+ \\
\text { Oxaliplatin }+ \\
\text { Lapatinib }\end{array}$ & $\begin{array}{l}\text { Capecitabine } \\
+ \text { Oxaliplatin } \\
+ \text { Placebo }\end{array}$ & III & I & OS & \begin{tabular}{l|}
53 \\
$(95 \%$ CI $46.6-$ \\
$59.3)$ \\
Vs. \\
40 \\
$(95 \%$ CI $33.6-$ \\
$46.4)$ \\
\end{tabular} & $\begin{array}{l}6.0 \text { vs. } 5.4 \\
\mathrm{HR}=0.86 \\
95 \% \mathrm{CI} \\
0.71-1.04 \\
p=0.10\end{array}$ & $\begin{array}{l}12.2 \quad v s . \\
10.5 \\
\mathrm{HR}=0.91 \\
95 \% \mathrm{CI} \\
0.73-1.12 \\
p=0.3492\end{array}$ \\
\hline $\begin{array}{l}\text { TyTAN } \\
\text { NCT00486954 }\end{array}$ & $\begin{array}{l}\text { Paclitaxel } \\
\text { Lapatinib }\end{array}$ & $\begin{array}{l}\text { Paclitaxel }+ \\
\text { Placebo }\end{array}$ & III & II & OS & $\begin{array}{l}27 \text { vs. } 9 \\
\mathrm{OR}=3.85 \\
95 \% \mathrm{CI} \\
1.80-8.87 \\
p<0.001\end{array}$ & $\begin{array}{l}5.4 \text { vs. } 4.4 \\
\mathrm{HR}=0.85 \\
95 \% \mathrm{CI} \\
0.63-1.13 \\
p=0.2441\end{array}$ & $\begin{array}{l}11.0 \text { vs. } 8.9 \\
\mathrm{HR}=0.84 \\
95 \% \mathrm{CI} \\
0.64-1.11 \\
p=0.2088\end{array}$ \\
\hline $\begin{array}{l}\text { GATSBY } \\
\text { NCT01641939 }\end{array}$ & $\begin{array}{l}\text { TDM-1 } \\
3.6 \mathrm{mg} / \mathrm{kg} \mathrm{q} 21 \\
\text { or } \\
\text { TDM-1 } \\
2.4 \mathrm{mg} / \mathrm{kg} \mathrm{q} 7\end{array}$ & $\begin{array}{l}\text { Paclitaxel or } \\
\text { Docetaxel }\end{array}$ & II/III & II & OS & 20.6 vs 19.6 & $\begin{array}{l}2.7 \text { vs } 2.9 \\
\mathrm{HR}=1.13 \\
95 \% \mathrm{CI} \\
0.89-1.43 \\
p=0.31\end{array}$ & $\begin{array}{l}7.9 \text { vs } 8.6 \\
\mathrm{HR}=1.15 \\
95 \% \mathrm{CI} \\
0.87-1.51 \\
p=0.86\end{array}$ \\
\hline
\end{tabular}

5-FU: 5-fluorouracil, CI: confidence interval, HR: hazard ratio, OR: odds ratio, iv: intravenous, ORR: overall response rate, OS: overall survival, PFS: progression-free survival, TDM-1: trastuzumab emtansine.

with IHC HER-2 3+ score, as well as the different rate of potentially active third-line treatments between study arms. Moreover, in TRIO-013/LOGiC trial, no correlation was observed between IHC status and OS benefit. Despite these uncertainties, lapatinib was not approved for gastric cancer. Key results of the most important randomized trials are summarized in Table 2. Ongoing studies might better define its role in combination with other targeted agents. Pertuzumab, a recombinant, humanized

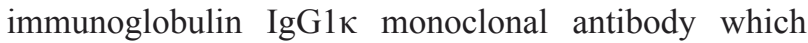
binds to the extracellular domain of HER-2 preventing its heterodimerization with other members of the HERfamily (HER-1, HER-3, and HER-4), has been studied to overcome trastuzumab resistance. Pertuzumab and trastuzumab bind to distinct epitopes of HER-2 without competing with each other and have complementary mechanisms of HER-2 signaling disruption, resulting in synergistic antiproliferative activity both in vitro and in vivo. Based on the promising results from preclinical trials [42], the encouraging activity reported in early clinical trials enrolling gastric cancer patients [43], and the great efficacy of the combination of trastuzumab and pertuzumab in breast cancer [44], the phase III JACOB trial (BO 25114) was designed to assess whether the addition of pertuzumab to cisplatin, 5-Fluorouracil and trastuzumab may further improve the survival of HER2- positive gastric cancer patients with an acceptable safety profile [45]. Investigators reached the recruitment target of 780 patients enrolled in the JACOB study on January 2016 and results from this important trial are eagerly awaited. Moreover, an ongoing randomized phase IIa study is enrolling previously untreated advanced gastric cancer patients to better characterize the pharmacokinetics and safety of pertuzumab [43]. Novel strategies to target HER-2 include the combination of cytotoxic agents and antibodies with high activity like trastuzumab emtansine (TDM-1). This antibody, specifically designed to deliver an antiproliferative agent to HER-2 overexpressing cancer cells, conjugates the targeted anti-HER-2 activity of trastuzumab with the intracellular cytotoxic effect of emtansine, a tubulin polymerase inhibitor [46]. In a multicenter, randomized Phase II/III study the efficacy and safety of TDM-1 was compared to standard taxane treatment in patients with HER2-positive pretreated advanced gastric cancer. Participants were randomized to receive either trastuzumab emtansine $3.6 \mathrm{mg} / \mathrm{kg}$ every 3 weeks or trastuzumab emtansine $2.4 \mathrm{mg} / \mathrm{kg}$ every week or single-agent taxane (docetaxel or paclitaxel as per investigator choice). The aim of the first phase of the study was to choose the optimal TDM-1 dose and schedule. Despite better safety profile of TDM-1, accrual has been prematurely discontinued for failure of primary 
Table 3: Principal ongoing trials in neoadjuvant HER2-positive gastric or gastroesophageal cancer.

\begin{tabular}{|c|c|c|c|c|}
\hline \multirow[t]{2}{*}{ TRIAL } & \multicolumn{2}{|l|}{ REGIMEN } & \multirow[t]{2}{*}{ PHASE } & \multirow[t]{2}{*}{$\begin{array}{l}\text { PRIMARY } \\
\text { ENDPOINT } \\
\end{array}$} \\
\hline & Experimental Arm & Control Arm & & \\
\hline $\begin{array}{l}\text { HERFLOT } \\
\text { NCT01472029 }\end{array}$ & $\begin{array}{l}\text { 5-FU } \\
\text { + Leucovorin } \\
\text { + Oxaliplatin } \\
\text { + Docetaxel } \\
\text { + Trastuzumab } 6 \mathrm{mg} / \mathrm{kg} \text { iv loading } \\
\text { dose, followed by } 4 \mathrm{mg} / \mathrm{kg} \text { iv every } \\
2 \text { weeks }\end{array}$ & $\begin{array}{l}\text { 5-FU } \\
\text { + Leucovorin } \\
\text { + Oxaliplatin } \\
\text { + Docetaxel }\end{array}$ & II & $\mathrm{pCR}$ \\
\hline $\begin{array}{l}\text { PETRARCA } \\
\text { NCT02581462 }\end{array}$ & $\begin{array}{l}\text { 5-FU } \\
\text { + Leucovorin } \\
\text { + Oxaliplatin } \\
\text { + Docetaxel } \\
\text { + Trastuzumab } 8 \mathrm{mg} / \mathrm{kg} \text { iv loading } \\
\text { dose, followed by } 6 \mathrm{mg} / \mathrm{kg} \text { iv every } \\
3 \text { weeks } \\
\text { +Pertuzumab } 840 \mathrm{mg} \text { every } 3 \text { weeks }\end{array}$ & $\begin{array}{l}\text { 5-FU } \\
\text { + Leucovorin } \\
\text { + Oxaliplatin } \\
\text { + Docetaxel }\end{array}$ & II/III & $\mathrm{pCR} / \mathrm{PFS}$ \\
\hline $\begin{array}{l}\text { INNOVATION } \\
\text { NCT02205047 }\end{array}$ & $\begin{array}{l}\text { 5-FU/Capecitabine } \\
\text { + Cisplatin } \\
\text { + Trastuzumab/Pertuzumab }\end{array}$ & $\begin{array}{l}\text { 5-FU/Capecitabine } \\
+ \text { Cisplatin }\end{array}$ & II & $\mathrm{pCR}$ \\
\hline $\begin{array}{l}\text { TOXAG } \\
\text { NCT01748773 }\end{array}$ & $\begin{array}{l}\text { RT at Total dose of } 45 \mathrm{~Gy} \text { divided } \\
\text { into } 25 \text { doses } \\
\text { +Capecitabine } \\
+ \text { Oxaliplatin } \\
+ \text { Trastuzumab } 8 \mathrm{mg} / \mathrm{kg} \text { iv loading } \\
\text { dose, followed by } 6 \mathrm{mg} / \mathrm{kg} \text { iv every } \\
3 \text { weeks }\end{array}$ & $/ /$ & II & Safety \\
\hline $\begin{array}{l}\text { RTOG } 1010 \\
\text { NCT01196390 }\end{array}$ & $\begin{array}{l}\text { RT } \\
+ \text { Paclitaxel } \\
+ \text { Carboplatin } \\
+ \text { Trastuzumab }\end{array}$ & $\begin{array}{l}\text { RT } \\
+ \text { Paclitaxel } \\
+ \text { Carboplatin }\end{array}$ & III & DFS \\
\hline
\end{tabular}

5-FU: 5-fluorouracil, OS: overall survival, PFS: progression-free survival, RT: radiotherapy, iv: intravenous, pCR: pathological complete response, DFS: disease free survival.

endpoint at first interim analysis [47]. Although a number of molecular mechanisms underpinning resistance to trastuzumab-based therapies have been already identified, a thorough investigation of such mechanisms will help clinicians to appropriately design future trials $[8,48]$.

One of the possible mechanisms associated with trastuzumab resistance is the deregulation of HER-2 downstream signal, including the PI3K/AKT/mTOR pathway. It is well known that PIK3CA mutations and PTEN inactivation result in constitutive activation of the downstream signals [49]. Everolimus, an orally administered mTOR inhibitor, showed enhanced 5-FUinduced apoptosis in gastric cancer cells with HER-2 amplification and promising activity in preclinical and early clinical trials $[50,51]$ : such results, however, have not been confirmed in the phase III GRANITE-1 trial. [52]. It is uncertain whether the combination of HER2targeted agents and mTOR inhibitors might provide benefit in patients with HER2-positive gastric cancer who became resistant: the identification of predictive biomarkers remains crucial for optimizing efficacy.

Afatinib, an oral irreversible inhibitor of tyrosine kinase receptors targeting HER-1, HER-2 and HER-4, may help overcoming trastuzumab resistance. Preliminary data of a phase II study enrolling patients with metastatic HER2-positive (IHC 3+ or FISH >2.0) esophagogastric cancer with disease progression whilst on a trastuzumabcontaining regimen have been recently presented $[53,54]$ with demonstration of a $40 \%$ disease control.

As pan-HER inhibitors have shown significant antitumor effects in vitro as well as in xenograft model of HER2-positive gastric cancer [55], the efficacy and safety of dacomitinib, an irreversible pan-HER tyrosine kinase inhibitor, was investigated in advanced gastric cancer patients. Twenty-seven pretreated gastric cancer patients received dacomitinib $45 \mathrm{mg}$ once daily continuously every 4 weeks. The 4-months PFS rate, the primary endpoint of the study, was $22.2 \%$ and median PFS was 2.1 months (95\% CI 2.3-3.4). Disease control rate was 40.7\% (95\% CI 21.9-59.6\%). Median OS was 7.1 months (95\% CI 4.49.8). The most common adverse events were skin rash, diarrhea, and fatigue, while no treatment-related deaths were seen [56].

Moreover, data suggest that HER-3 might play a key role in tumorigenesis and act as a mediator of resistance to HER-2 inhibitors. MM-111, a novel molecule that inhibits heregulin-activated HER-3 signaling, has been shown to mitigate HER3-mediated resistance in preclinical gastric 
Table 4: Principal ongoing trials in advanced HER2-positive gastric cancer.

\begin{tabular}{|c|c|c|c|c|c|}
\hline \multirow[t]{2}{*}{ TRIAL } & \multicolumn{2}{|l|}{ REGIMEN } & \multirow[t]{2}{*}{ PHASE } & \multirow[t]{2}{*}{ LINE } & \multirow[t]{2}{*}{\begin{tabular}{|l|} 
PRIMARY \\
ENDPOINT \\
\end{tabular}} \\
\hline & Experimental Arm & Control Arm & & & \\
\hline $\begin{array}{l}\text { HELOISE } \\
\text { NCT01450696 }\end{array}$ & $\begin{array}{l}\text { Capecitabine } \\
+ \text { Cisplatin } \\
+ \text { Trastuzumab } 8 \mathrm{mg} / \mathrm{kg} \text { iv loading dose, } \\
\text { followed } 10 \mathrm{mg} / \mathrm{kg} \text { iv every } 3 \text { weeks }\end{array}$ & $\begin{array}{l}\text { Capecitabine } \\
+ \text { Cisplatin } \\
+ \text { Trastuzumab } 8 \mathrm{mg} / \mathrm{kg} \text { iv loading dose, } \\
\text { followed by } 6 \mathrm{mg} / \mathrm{kg} \text { iv every } 3 \text { weeks }\end{array}$ & III & I & OS \\
\hline $\begin{array}{l}\text { JACOB } \\
\text { NCT01774786 }\end{array}$ & $\begin{array}{l}\text { Capecitabine/5-FU } \\
\text { + Cisplatin } \\
\text { + Trastuzumab } \\
\text { + Pertuzumab }\end{array}$ & $\begin{array}{l}\text { Capecitabine/5-FU } \\
\text { + Cisplatin } \\
\text { + Trastuzumab } \\
\text { + Placebo }\end{array}$ & III & I & OS \\
\hline NCT01774851 & $\begin{array}{l}\text { Paclitaxel } \\
\text { + Trastuzumab } \\
\text { + MM-111 }\end{array}$ & $\begin{array}{l}\text { Paclitaxel } \\
\text { + Trastuzumab }\end{array}$ & II & II & PFS \\
\hline
\end{tabular}

5-FU: 5-fluorouracil, OS: overall survival, PFS: progression-free survival. iv: intravenous

models [57]; thus, it is being tested within different trials in order to assess whether its addition might lead to an increased antitumor activity of trastuzumab and paclitaxel. [58]. Recent advances in HER-2 biology have expanded the use of HER-2 inhibitors in gastric cancer patients. Nevertheless, the underpinning molecular mechanisms of gastric cancer progression as well as the strategies to overcome resistance need to be further elucidated. International collaborative efforts to improve the knowledge on the background biology of this disease are ongoing (Table 3 and Table 4), as well as clinical and translational studies testing other novel HER-2 inhibitors.

\section{HER-2: A NOVEL POTENTIAL TARGET IN COLORECTAL CANCER}

In Western countries, CRC is one of the most common malignancies being the second leading cause of cancer-related death in the United States [17]. Despite the treatment advances achieved so far, with OS overcoming 30 months in genetically selected patients, metastatic CRC remains an incurable disease [59-62]. It is worth noting that, although most of the patients who have exhausted all standard treatments usually have a limited survival $[63,64]$, some of them may still have a good performance status and strongly desire further treatment. Paramount discoveries about the molecular biology underpinning CRC have been made [65], but we are still far from a thorough understanding of the tumor biology and the role of HER-2 overexpression and amplification in CRC.

HER-2 protein is usually weakly expressed in the membrane and/or cytoplasm of colonic epithelium, whereas the membrane of tumor cells may have various staining patterns [66].

The incidence of HER-2 expression in colon adenocarcinoma ranges from $0 \%$ to $83 \%$ [67-69] and reports on HER-2 gene amplification and HER-2 overexpression in metastatic CRC have been discordant.
It is commonly agreed that such wide range may reflect differences in technical approaches, antibodies used, and scoring protocols, as well as study biases associated with patient selection [70, 71]. Most of the studies showed membranous overexpression rates between 0 and $15 \%$. Of note, some studies reported higher rates of both membranous and cytoplasmic overexpression, up to $60 \%$. Major hurdles in comparing HER-2 IHC studies in CRC are the variety of antibodies used as well as how technical issues are differently handled across protocols such as tissue fixation, slide storage procedures, antigen retrieval, and incubation time. To overcome such problems, a standard and reproducible staining procedure is highly needed. Overall, about $5 \%$ of CRC have HER2 membranous overexpression, far lower than what it is observed in breast cancer [72,73], while the cytoplasmic overexpression varies strongly with an average of $30 \%$. However, it is likely that this value is underestimated due to the loss of HER-2 antigen in older tissue samples [74].

The disagreement in evaluating HER-2 expression at every level (nuclear, cytoplasmic and cell surface) emphasizes the limitations of using IHC evaluation alone and points out the need for further predictive biomarkers for HER2-targeted therapies in tumors displaying overexpression in gene copy number, mRNA and receptor protein [71].

Several studies analyzed HER-2 overexpression in $\mathrm{CRC}$ with genomic techniques such as fluorescence in situ hybridization (FISH), reverse transcription polymerase chain reaction (RT-PCR), Southern blotting, and Northern blotting. Altogether, these results confirmed that IHC $3+$ overexpression is conclusive for gene amplification, whereas $2+$ staining may be equivocal and likely associated with other mechanisms of genetic overexpression [74].

In a retrospective study, Tu et al. described a consistency between the levels of HER-2 protein expression determined by IHC and HER-2 gene 
amplification determined by FISH in 102 HER-2 overexpressed CRC samples. A relatively high level of consistency was observed between IHC $0 / 1+/ 3+$ with FISH $(24.5 \%$ of the IHC $3+$ cases showed HER2 gene amplification by FISH and none of the 20 randomly selected IHC $0 / 1+$ cases demonstrated FISH amplification); however, there was a low level of consistency between IHC $2+$ results and FISH. Of note, no association between HER-2 overexpression or gene amplification and survivorship was seen. [75]

In $\mathrm{CRC}$, the clinical significance of HER-2 is still controversial. While some data seem to link HER2 overexpression to decreased survival, suggesting that HER-2 may be a potential negative prognostic factor, other studies failed to confirm similar results [74]. Additionally, it is unclear whether HER-2 may be exploited as a potential therapeutic target in CRC patients [67].

$\mathrm{CRC}$ is a highly heterogeneous disease meaning, from a practical point of view, that some of the cellular clones will be sensitive to specific therapies while others will be not. Moreover, this heterogeneity dynamically varies under treatment pressure: while sensible clones start to disappear, resistant clones may eventually emerge and expand leading to disease progression. At this point, a new treatment may overcome resistance to previous compounds, determining another cancer clone remodeling [12-14]. As such, the selection of patients for a specific treatment is fundamental and, when available, predictive factors to both response and resistance are to be considered. Cetuximab and panitumumab, two epidermal growth factor receptor (EGFR) inhibitors approved for the treatment of metastatic CRC, are a stark example of this. KRAS, NRAS, BRAF, and possibly PIK3CA mutations prevent the efficacy of these drugs, confirming that constitutive activation of parallel or downstream pathways may bypass EGFR inhibition. Since EGFR may also heterodimerize with other members of HER family, it is reasonable to consider HER-2 as an additional response predictor [16].

In truth, HER-2 amplification seems to be associated with KRAS wild-type tumors and may cause acquired resistance to EGFR inhibition [15]. In the largest case series ever published, including tissue samples of 1,645 primary CRC patients, HER-2 status was assessed by IHC using the monoclonal antibody SP3. IHC 3+ score were reported as positive, $2+$ score as equivocal, and $0 / 1+$ score as negative. Tumors scoring $2+$ were further evaluated by CISH to assess HER-2 amplification. Only 9 cases were upfront scored as HER2-positive, while 35 cases showed an equivocal result. All cases scored $2+$ and $3+$, and 54 randomly selected $0 / 1+$ cases were additionally tested on whole tissue sections. Overall, $1.6 \%$ of the whole CRC cohort was HER2-positive (26 out of 1,645). No differences between HER-2 status on primary tissue sample and resected locoregional nodes were reported. HER-2 positivity significantly correlated with higher stage at diagnosis and with the presence of nodal metastasis. Although not statistically significant, the rate of HER2 positivity was higher in rectal than in colon cancers. Despite a trend toward worse prognosis, HER2-positivity had no significant impact on survival [76]. In line with these results, other recent series including a smaller number of patients have confirmed a similar low rate of HER-2 positivity in patients with CRC $[66,77]$ or rectal cancer [78].

In order to explore whether HER-2 was overexpressed and/or amplified in tumors from patients resistant to anti-EGFR antibodies, Bertotti et al. used direct transfer xenografts as a new strategy to anticipate clinical findings and to possibly optimize tailored treatment for these patients. For each tumor specimen, some fragments were subcutaneously implanted in immunodeficient mice and then expanded to generate a pair of independent xenograft lines for each patient (xenopatients). HER-2 amplification/overexpression was reported only in KRAS wild-type tumors that progressed on cetuximab or panitumumab [15], suggesting that HER2 amplification may limit EGFR-inhibitors activity in RAS wild-type tumors.

Whether HER-2 gene copy number status may influence the response to cetuximab or panitumumab has also been retrospectively assessed in a large cohort of patients, who were divided into three groups according to their FISH evaluation. The results of this analysis showed that HER-2 amplification was associated with EGFR-inhibitors resistance and affected both PFS and OS [16]. Such findings support the results by Bertotti et al. and those by Yonesaka et al., who highlighted how the activation of ERBB2 signaling causes resistance to cetuximab leading to a worse prognosis [79].

The potential role of HER-2 in inducing resistance in CRC cells exposed to EGFR-inhibitors, was further investigated in a preclinical study where the impact of somatic mutations by introducing the HER2 V842I mutation, the most prevalent HER-2 mutation identified in CRC samples according to the Cancer Genome Atlas [80], into the cetuximab-sensitive colorectal cell line DiFi was assessed. The introduction of the V842I mutation caused a 40- to 100-fold shift in the half maximal inhibitory concentration (IC50) values of both cetuximab and panitumumab. Moreover, the impact of five HER-2 mutations in another cetuximab-sensitive CRC cell line (NCI-H508) was explored showing that all mutations led to the emergence of EGFR-inhibitors resistance. Western blots of the EGFR-HER2 signaling pathways suggested that the mechanism of anti-EGFR resistance consisted in sustaining MAPK phosphorylation. Based on preclinical studies, which showed that HER-2 mutations can be strongly inhibited by nanomolar doses of neratinib or afatinib [81, 82], both irreversible HER2/EGFR tyrosine kinase inhibitors were tested on DiFi and NCI-H508 cells transduced with HER-2 mutations leading to growth 
inhibition. Moreover, the authors sequenced the HER2 gene of 48 CRC patient-derived xenografts (PDX) samples that were cetuximab-resistant and wild-type (WT) for KRAS, NRAS, BRAF, and PIK3CA (quadruple WT): four of these PDXs had HER-2 mutations. The effect of HER2-targeted therapies on two of these PDXs was assessed: single agent HER2-targeted therapy (with either trastuzumab, neratinib, or lapatinib) delayed the growth of these PDXs, while dual HER2-targeted therapy (with either trastuzumab plus neratinib or trastuzumab plus lapatinib) produced durable tumor regression [83].

Leto and coll. investigated the underlying cooperative mechanisms of co-targeting HER-2 with a monoclonal antibody and a small molecule. They evaluated the phosphorylation/activation of HER-2, HER-3, EGFR (HERs) and downstream transducers in HER2-overexpressing colorectal and gastric cancer cell lines; in addition, the in vivo outcome of antibodymediated HER-2 blockade with trastuzumab, reversible HER2-inhibition by lapatinib, and irreversible HER2inhibition by afatinib inpatient-derived tumorgrafts and cell-line xenografts was also assessed. The results of the study showed that trastuzumab monotherapy reduced HER-3 phosphorylation, with minor consequences on downstream transducers, while lapatinib acutely inhibited all HER receptors and effectors but led to delayed re-phosphorylation of HER-3 and EGFR and partial restoration of ERK and AKT activity. When combined with lapatinib, trastuzumab prevented HER3/EGFR reactivation and caused prolonged inhibition of ERK/ AKT. Interestingly, afatinib alone was also very effective in counteracting the reinstatement of HER-3, EGFR, and downstream signaling activation. In vivo, the combination of trastuzumab and lapatinib or single-agent afatinib resulted in evident tumor shrinkage. Taken together, these findings showed that only prolonged inhibition of HER-3 and EGFR, achievable by dual blockade with trastuzumab and lapatinib or irreversible HER-2 inhibition by afatinib, led to regression of HER2-amplified gastrointestinal carcinomas [84]. These preclinical findings should be tested in clinical trials in order to validate the potential role of HER-2 as a target [85].

Whether HER-2 amplification is associated with specific clinico-pathological characteristics of CRC has also been studied. In a recent report, no association between HER-2 overexpression and gender, age, tumor site, size, depth of invasion, lymph node metastases or distant metastases was observed. In addition, no significant survival differences between tumors with or without HER-2 amplification were noted [75]. In other case series, HER-2 overexpression was not shown to be more frequently associated with microsatellite instability (MSI) or infiltrative tumor border, invasion depth, lymph node metastasis, distant metastasis, and perineural invasion. Both HER-2 overexpression and HER-2 gene amplification, however, were associated with rectal tumor location [66]. Accordingly, Missiaglia et al. observed that distal carcinomas are more often HER-2 amplified compared to proximal ones [86]. Concordance between primary tumor and distant metastases of HER-2 positivity has also been investigated $[67,87]$. As a matter of fact, Lee et al. assessed in both primary and distant lesion KRAS and HER-2 status of 94 consecutive CRC patients who underwent curative resection of the primary tumor and liver or lung metastases. HER-2 protein overexpression was assessed by IHC, with only $2.1 \%$ of cases overexpressed. HER-2 amplification was observed in $10.1 \%$ of combined primary tissue and metastases, suggesting high levels of concordance between primary disease and paired secondary lesions [67]. In a retrospective Italian study that enrolled $50 \mathrm{CRC}$ patients neurosurgically resected for secondary brain lesions, the overall HER-2 positivity of brain metastases was $12 \%$, and a concordance rate of $89 \%$ between primary tumor and distant lesion was reported [87]. In line with these results, a high concordance between the primary tumor and liver metastasis was also described in another study [88] thus suggesting that metastatic lesions may also be suitable for anti-HER-2 therapy.

The predictive role of HER-2 in CRC has been recently unveiled. Unlike cetuximab and panitumumab, treatment response to trastuzumab highly depends on HER-2 protein overexpression and gene amplification. Since approximately $5 \%$ of all CRC patients have membranous overexpression, HER-2 inhibitors were supposed to be effective only in a small subgroup of patients, who should be therefore selected based on of their HER-2 expression pattern. The definition of the role of anti-HER-2 treatment for metastatic CRC has not been straightforward with two pivotal clinical trials prematurely closed due to a slow accrual: the low incidence of HER2 overexpression was to blame for such failure [89, 90]. Moreover, a phase II study failed to show sufficient activity for the combination of capecitabine and lapatinib in patients with refractory intestinal adenocarcinoma [91], while preclinical synergy was demonstrated for the oral HER-2 inhibitor combined with panobinostat, a histone deacetylase inhibitor $[75,92]$. Whether HER-2 inhibition could restore sensitivity to EGFR inhibitors was also studied. A phase I/II trial has been conducted to assess the efficacy and safety of cetuximab in combination with pertuzumab in patients with cetuximab-resistant metastatic CRC. Despite an encouraging RR, the study was prematurely stopped due to severe overlapping toxicities of the two compounds, which included severe skin rash, mucositis and diarrhea [93].

The HERACLES trial (HER2 Amplification for Colo-rectaL Cancer Enhanced Stratification) tested the combination of trastuzumab plus lapatinib or pertuzumab in metastatic HER2-amplified CRC patients. A validation study was conducted in order to develop a validated ERBB2 scoring system for colorectal cancer with the 
aim of identifying ERBB2-positive patients suitable for enrollment in the HERACLES trial [94]. In both archival test cohort $(n=256)$ and in the validation cohort $(n=830)$ a $5 \%$ of KRAS wild-type pretreated CRC patients were found to be HER2-positive. In the phase II HERACLES trial, 23 heavily pretreated KRAS wild-type, HER2positive patients (IHC $3+$ or $2+$ and FISH positive with HER-2-to-CEP17 ratio $>2$ ), refractory to all standard agents including fluoropyrimidines, oxaliplatin, irinotecan, bevacizumab, and EGFR-inhibitors, were treated with trastuzumab and lapatinib. The primary trial endpoint was RECIST-determined objective RR.

Overall, 913 patients were screened, 44 were found to be HER2-positive and 23 were enrolled $(2.3 \%$ of those screened). The Italian investigators observed 8 responses out of 23 treated patients (ORR 32\%) and the trial met its primary endpoint before the enrollment was completed, with a median time to progression of 5.5 months $(95 \% \mathrm{CI}$ 3.7-9.8) and some long-lasting responders. HERACLES, the first precision medicine trial with positive results in advanced CRC, proved that the combination of trastuzumab and lapatinib is clinically effective in HER2positive heavily pretreated metastatic CRC patients. As such, this combination needs to be further investigated in earlier treatment lines [95].

Finally, HER-2 can be immunogenic and generate antibodies and activation of T lymphocytes, suggesting that it can also be a target for $\mathrm{T}$ cell-directed immunotherapy [71]. Like in sarcomas, which are also tumors that express HER-2 at too low levels for HER-2 monoclonal antibodies to be effective, the role of immunotherapy with $\mathrm{T}$ cells genetically modified to express HER-2 may also be tested in metastatic CRC [96]; this might be an interesting option that could be considered for those metastatic CRC patients displaying cytoplasmic HER-2 overexpression [71].

Taken together, these pre-clinical and clinical data, pose HER-2 as an attractive object of interest, mainly from a therapeutic point of view, in the treatment of metastatic CRC. The assessment of HER-2 status may therefore be useful both as predictive factor of response to treatment with EGFR-inhibitors both as the main therapeutic target in a percentage, albeit small, of patients suffering from metastatic CRC. In this context, it would be useful to plan clinical trials testing the activity of anti-HER2 agents not only as drugs able to restore the sensitivity to EGFRinhibitors, but also in a first line setting. For these reasons, despite HER2-positivity is observed more often in RAS wt disease, it might be useful to assess the HER-2 status both since the diagnosis of metastatic CRC and subsequently during biopsy of a metastatic site.

\section{CONCLUSIONS}

Although palliative chemotherapy may improve both patient's outcome and quality of life, its overall benefit is still limited. However, with the introduction of novel targeted therapies, the median survival of gastrointestinal malignancies is slowly but constantly improving, but a thorough understanding of CRC molecular biology is required to develop new targeted compounds.

Significant benefits have been observed with trastuzumab in HER2-positive tumors but the journey to a full implementation of anti-HER-2 therapy has just begun. Ongoing clinical trials are aiming at a better patient selection mainly according to the tumor molecular profile. Evidence that HER-2 overexpression drives progression and resistance to therapy in a limited subset of gastrointestinal cancers, thus becoming a valid drug target in this setting, has represented a major step forward in tailoring cancer therapy. However, anti-HER-2 treatment, even when tested in a selected biomarkerpositive population, provides only modest survival gains $[9,95]$, given the inevitable development of acquired resistance. Intratumour heterogeneity, supporting clonal evolution under treatment pressure, is the main culprit for the emergence of resistance [97]. Additional oncogenic and epigenetic events have also been reported to confer resistance to HER-2 treatment in gastrointestinal cancers, suggesting that combination inhibitory strategies should be pursued to effectively prevent or delay the development of resistance [92]. Moreover, understanding secondary features that contribute to resistance, may allow the development of rational combination approaches to improve the efficacy of anti-HER-2 treatment in gastrointestinal cancers. To accomplish this, "liquid biopsies" allow a dynamic monitoring of clonal evolution, providing a valid tool to maximize anti-HER-2 treatment for gastrointestinal cancers [12].

This will ultimately help clinicians to administer the right treatment to the right patient increasing survival, decreasing side effects and finally improving quality of life.

\section{CONFLICTS OF INTEREST}

The authors have no conflict of interest to disclose.

\section{REFERENCES}

1. Slamon DJ, Godolphin W, Jones LA, Holt JA, Wong SG, Keith DE, Levin WJ, Stuart SG, Udove J, Ullrich A. Studies of the HER-2/neu proto-oncogene in human breast and ovarian cancer. Science. 1989; 244: 707-12.

2. Neve RM, Lane HA, Hynes NE. The role of overexpressed HER2 in transformation. Ann Oncol. 2001; 12 Suppl 1: S913.

3. Rubin I, Yarden Y. The basic biology of HER2. Ann Oncol. 2001; 12 Suppl 1: S3-8.

4. Ross JS, Fletcher JA. The HER-2/neu Oncogene in Breast Cancer: Prognostic Factor, Predictive Factor, and Target for Therapy. Oncologist. 1998; 3: 237-252. 
5. Cooke T, Reeves J, Lanigan A, Stanton P. HER2 as a prognostic and predictive marker for breast cancer. Ann Oncol. 2001; 12 Suppl 1: S23-8.

6. Begnami MD, Fukuda E, Fregnani JH, Nonogaki S, Montagnini AL, da Costa WL Jr, Soares FA. Prognostic implications of altered human epidermal growth factor receptors (HERs) in gastric carcinomas: HER2 and HER3 are predictors of poor outcome. J Clin Oncol. 2011; 29: 3030-6.

7. Scartozzi M, Pistelli M, Bittoni A, Giampieri R, Galizia E, Berardi R, Faloppi L, Del Prete M, Cascinu S. Novel perspectives for the treatment of gastric cancer: from a global approach to a personalized strategy. Curr Oncol Rep. 2010; 12: 175-85.

8. Aprile G, Giampieri R, Bonotto M, Bittoni A, Ongaro E, Cardellino GG, Graziano F, Giuliani F, Fasola G, Cascinu S, Scartozzi M. The challenge of targeted therapies for gastric cancer patients: the beginning of a long journey. Expert Opin Investig Drugs. 2014; 23: 925-42.

9. Bang YJ, Van Cutsem E, Feyereislova A, Chung HC, Shen L, Sawaki A, Lordick F, Ohtsu A, Omuro Y, Satoh T, Aprile G, Kulikov E, Hill J, Lehle M, Rüschoff J, Kang YK; ToGA Trial Investigators. Trastuzumab in combination with chemotherapy versus chemotherapy alone for treatment of HER2-positive advanced gastric or gastro-oesophageal junction cancer (ToGA): a phase 3, open-label, randomised controlled trial. Lancet. 2010; 376: 687-97.

10. Aprile G, Bonotto M, Ongaro E, Pozzo C, Giuliani F. Critical appraisal of ramucirumab (IMC-1121B) for cancer treatment: from benchside to clinical use. Drugs. 2013; 73: 2003-15.

11. Aprile G, Ongaro E, Del Re M, Lutrino SE, Bonotto M, Ferrari L, Rihawi K, Cardellino GG, Pella N, Danesi R, Fasola G. Angiogenic inhibitors in gastric cancers and gastroesophageal junction carcinomas: A critical insight. Crit Rev Oncol Hematol. 2015; 95: 165-78.

12. Siravegna G, Mussolin B, Buscarino M, Corti G, Cassingena A, Crisafulli G, Ponzetti A, Cremolini C, Amatu A, Lauricella C, Lamba S, Hobor S, Avallone A,et al. Clonal evolution and resistance to EGFR blockade in the blood of colorectal cancer patients. Nat Med. 2015; 21: 795-801. doi: 10.1038/nm.3870.

13. Stahl PR, Schnellert J, Koop C, Simon R, Marx A, Izbicki JR, Sauter G, Quaas A. Determination of tumor heterogeneity in colorectal cancer using heterogeneity tissue microarrays. Pathol Oncol Res. 2015; 21: 1183-9. doi: 10.1007/s12253-015-9953-4.

14. Dienstmann R, Salazar R, Tabernero J. Overcoming resistance to anti-EGFR therapy in colorectal cancer. Am Soc Clin Oncol Educ Book. 2015; 35: e149-56.

15. Bertotti A, Migliardi G, Galimi F, Sassi F, Torti D, Isella C, Corà D, Di Nicolantonio F, Buscarino M, Petti C, Ribero D, Russolillo N, Muratore A, et al. A molecularly annotated platform of patient-derived xenografts ("xenopatients") identifies HER2 as an effective therapeutic target in cetuximab-resistant colorectal cancer. Cancer Discov. 2011; 1: 508-23.

16. Martin V, Landi L, Molinari F, Fountzilas G, Geva R, Riva A, Saletti P, De Dosso S, Spitale A, Tejpar S, Kalogeras KT, Mazzucchelli L, Frattini M,et al. HER2 gene copy number status may influence clinical efficacy to anti-EGFR monoclonal antibodies in metastatic colorectal cancer patients. Br J Cancer. 2013; 108: 668-75.

17. Siegel R, Ma J, Zou Z, Jemal A. Cancer statistics, 2014. CA Cancer J Clin. 2014; 64: 9-29.

18. Aprile G, Silvestris N, Antonuzzo L, Scartozzi M. Metastatic gastric cancer in the last two decades: goals achieved and future promises. Future Oncol. 2015.

19. Sakai K, Mori S, Kawamoto T, Taniguchi S, Kobori O, Morioka Y, Kuroki T, Kano K. Expression of epidermal growth factor receptors on normal human gastric epithelia and gastric carcinomas. J Natl Cancer Inst. 1986; 77: 1047 52.

20. Fisher SB, Fisher KE, Squires MH 3rd, Patel SH, Kooby DA, El-Rayes BF, Cardona K, Russell MC, Staley CA 3rd, Farris AB 3rd, Maithel SK. HER2 in resected gastric cancer: Is there prognostic value? J Surg Oncol. 2014; 109: 61-6.

21. Tang D, Liu CY, Shen D, Fan S, Su X, Ye P, Gavine PR, Yin X. Assessment and prognostic analysis of EGFR, HER2, and HER3 protein expression in surgically resected gastric adenocarcinomas. Onco Targets Ther. 2014; 8: 7-14.

22. Jørgensen JT, Hersom M. HER2 as a Prognostic Marker in Gastric Cancer - A Systematic Analysis of Data from the Literature. J Cancer. 2012; 3: 137-44.

23. Dang HZ, Yu Y, Jiao SC. Prognosis of HER2 overexpressing gastric cancer patients with liver metastasis. World J Gastroenterol. 2012; 18: 2402-7.

24. Gómez-Martin C, Garralda E, Echarri MJ, Ballesteros A, Arcediano A, Rodríguez-Peralto JL, Hidalgo M, LópezRíos F. HER2/neu testing for anti-HER2-based therapies in patients with unresectable and/or metastatic gastric cancer. J Clin Pathol. 2012; 65: 751-7.

25. Hofmann M, Stoss O, Shi D, Büttner R, van de Vijver M, Kim W, Ochiai A, Rüschoff J, Henkel T. Assessment of a HER2 scoring system for gastric cancer: results from a validation study. Histopathology. 2008; 52: 797-805.

26. Lee S, de Boer WB, Fermoyle S, Platten M, Kumarasinghe MP. Human epidermal growth factor receptor 2 testing in gastric carcinoma: issues related to heterogeneity in biopsies and resections. Histopathology. 2011; 59: 832-40.

27. Gravalos C, Jimeno A. HER2 in gastric cancer: a new prognostic factor and a novel therapeutic target. Ann Oncol. 2008; 19: 1523-9.

28. Cancer Genome Atlas Research Network. Comprehensive molecular characterization of gastric adenocarcinoma. Nature. 2014; 513: 202-9.

29. Van Cutsem E, Bang YJ, Feng-Yi F, Xu JM, Lee KW, Jiao SC, Chong JL, López-Sanchez RI, Price T, Gladkov 
O, Stoss O, Hill J, Ng V, Lehle M, Thomas M, Kiermaier A, Rüschoff J. HER2 screening data from ToGA: targeting HER2 in gastric and gastroesophageal junction cancer. Gastric Cancer. 2015; 18: 476-84. doi: 10.1007/s10120014-0402-y.

30. Tajiri R, Ooi A, Fujimura T, Dobashi Y, Oyama T, Nakamura R, Ikeda $H$. Intratumoral heterogeneous amplification of ERBB2 and subclonal genetic diversity in gastric cancers revealed by multiple ligation-dependent probe amplification and fluorescence in situ hybridization. Hum Pathol. 2014; 45: 725-34.

31. Sapino A, Goia M, Recupero D, Marchiò C. Current Challenges for HER2 Testing in Diagnostic Pathology: State of the Art and Controversial Issues. Front Oncol. 2013; 3: 129.

32. Albarello L, Pecciarini L, Doglioni C. HER2 testing in gastriccancer. AdvAnatPathol. 2011; 18: 53-9.

33. HELOISE Study: A Study of Herceptin (Trastuzumab) in Combination With Cisplatin/Capecitabine Chemotherapy in Patients With HER2-Positive Metastatic Gastric or Gastro-Esophageal Junction Cancer. Available: https:// clinicaltrials.gov/ct2/show/NCT01450696?term=nct01450 696\&rank=1 (accessed 08.06.2015).

34. Cosson VF, Ng VW, Lehle M, Lum BI. Population exposure pharmacokinetics and exposure-response analyses of trastuzumab in patients with advanced gastric or gastroesophageal junction cancer. Cancer Chemother Pharmacol. 2014; 73; 737-47.

35. Hofheinz R, Hegewisch-Becker S, Thuss-Patience P, Kunzmann V, Fuchs M, Graeven U, Homann N, Heinemann V, Pohl M, Tanapfel A, Al-Batran SE. HERFLOT: Trastuzumab in combination with FLOT as perioperative treatment for patients with HER2-positive locally advanced esophagogastric adenocarcinoma: a phase II trial of the AIO gastric cancer Study group. J Clin Oncol. 2014 (suppl; abstr 4073).

36. FLOT vs FLOT/Herceptin/Pertuzumab for periopertive therapy of Her-2 expressin gastric or GEJ cancer (PETRARCA). Available: https://clinicaltrials.gov/ ct $2 /$ show/NCT02581462?term $=$ nct01450696\&rank $=1$ (accessed 06.02.2016).

37. NeoadjuvantStudy Using Trastuzumab or Trastuzumab With Pertuzumab in Gastric or Gastroesophageal Junction Adenocarcinoma (INNOVATION). Available: https:// clinicaltrials.gov/ct2/show/NCT02205047?term=nct02205 047\&rank=1 (accessed 08.06.2015).

38. A Study of the Combination of Oxaliplatin, Capecitabine and Herceptin (Trastuzumab) and Chemoradiotherapy in The Adjuvant Setting in Operated Patients With HER2+ Gastric or Gastro-Esophageal Junction Cancer (TOXAG Study). Available: https://clinicaltrials.gov/ct2/show/ NCT01748773?term $=$ nct01748773\&rank $=1 \quad$ (accessed 08.06.2015).

39. Radiation Therapy, Paclitaxel, and Carboplatin With or Without Trastuzumab in Treating Patients With Esophageal
Cancer. Available: https://clinicaltrials.gov/ct2/show/ NCT01196390?term $=$ nct01196390\&rank $=1 \quad$ (accessed 08.06.2015).

40. Hecht JR, Bang YJ, Qin S, Chung HC, Xu JM, Park JO, Jeziorski K, Shparyk Y, Hoff PM, Sobrero AF, Salman $\mathrm{P}$, Li J, Protsenko S, et al. Lapatinib in combination with capecitabine plus oxaliplatin (CapeOx) in Human Epidermal Growth Factor Receptor2-positive advanced or metastatic gastric, esophageal, or gastroesophagealadenoca rcinoma:The TRIO-013/LOGiC Trial A Randomized phase III trial. J Clin Oncol. 2013; (suppl; abstr LBA4001).

41. Satoh T, Xu RH, Chung HC, Sun GP, Doi T, Xu JM, Tsuji A, Omuro Y, Li J, Wang JW, Miwa H, Qin SK, Chung IJ, et al. Lapatinib plus paclitaxel versus paclitaxel alone in the second-line treatment of HER2-amplified advanced gastric cancer in Asian populations: TyTAN--a randomized, phase III study. J ClinOncol. 2014; 32:2039-49.

42. Yamashita-Kashima Y, Iijima S, Yorozu K, Furugaki K, Kurasawa M, Ohta M, Fujimoto-Ouchi K.Pertuzumab in combination with trastuzumab shows significantly enhanced antitumor activity in HER2-positive human gastric cancer xenograft models. Clin Cancer Res. 2011; 17:5060-70.

43. A Study of Pertuzumab in Combination With Trastuzumab and Chemotherapy in Patients With HER2-Positive Advanced Gastric Cancer. Available: https://clinicaltrials. gov/ct2/show/NCT01461057?term $=$ nct $+01461057 \&$ rank $=1$ (accessed 08.06.2015).

44. Baselga J, Cortés J, Kim SB, Im SA, Hegg R, Im YH, Roman L, Pedrini JL, Pienkowski T, Knott A, Clark E, Benyunes MC, Ross G,et al; CLEOPATRA Study Group. Pertuzumab plus trastuzumab plus docetaxel for metastatic breast cancer. N Engl J Med. 2012; 366:109-19.

45. A Study of Perjeta (Pertuzumab) in Combination With Herceptin (Trastuzumab) and Chemotherapy in Patients With HER2-Positive Metastatic Gastroesophageal Junction or Gastric Cancer. Available: https://clinicaltrials.gov/ ct $2 /$ show/NCT01774786?term $=$ nct01774786\&rank=1 (accessed 08.06.2015).

46. Ballantyne A, Dhillon S. Trastuzumab emtansine: first global approval. Drugs. 2013; 73:755-65.

47. Kang YK, Shah MA, Ohtsu A, Van Cutsem E, Ajani JA, van der Horst T, Harle-Yge ML, Piao Y, Althaus B, ThussPatience P. A randomized, open-label, multicenter, adaptive phase $2 / 3$ study of trastuzumab emtansine (T-DM1) versus a taxane (TAX) in patients (pts) with previously treated HER2-positive locally advanced or metastatic gastric/ gastroesophageal junction adenocarcinoma (LA/MGC/ GEJC). J Clin Oncol. 2016; (suppl 4S; abstr 5).

48. Boku N. HER2-positive gastric cancer. Gastric Cancer. 2014; 17:1-12.

49. Matsuoka T, Yashiro M. The Role of PI3K/Akt/mTOR Signaling in Gastric Carcinoma. Cancers (Basel). 2014; 6:1441-63.

50. Yeh KH, Chiang YW, Lin CS. Chemo-sensitizing effects 
and sustained G1-S cell cycle arrest by low-dose RAD001 (everolimus) for cisplatin and 5-fluorouracil in human gastric cancer cells. Proc Am Assoc Cancer Res. 2007; 58:957 (abstr 4043).

51. Doi T, Muro K, Boku N, Yamada Y, Nishina T, Takiuchi H, Komatsu Y, Hamamoto Y, Ohno N, Fujita Y, Robson M, Ohtsu A. Multicenter phase II study of everolimus in patients with previously treated metastatic gastric cancer. J Clin Oncol. 2010; 28:1904-10.

52. Ohtsu A, Ajani JA, Bai YX, Bang YJ, Chung HC, Pan HM, Sahmoud T,Shen L, Yeh KH, ChinK, Muro K, Kim YH, Ferry D,et al. Everolimus for previously treated advanced gastric cancer: results of the randomized, double-blind, phase III GRANITE-1 study. J Clin Oncol. 2013; 31:393543.

53. Janjigian YY, Ku GY, Ilson DH, Boyar MS, Capanu M, Chou JF. A phase II study of afatinib in patients (pts) with metastatic human epidermal growth factor receptor (HER2)-positive trastuzumab refractory esophagogastric (EG) cancer. J Clin Oncol. 2015; (suppl 3; abstr 59).

54. Afatinib (BIBW 2992) and Trastuzumab in Patients With Advanced HER2-Positive Trastuzumab-Refractory Advanced Esophagogastric Cancer. Available: https:// clinicaltrials.gov/ct2/show/NCT01522768?term=nct01522 768\&rank=1 (accessed 08.06.2015).

55. Nam HJ, Ching KA, Kan J, Kim HP, Han SW, Im SA, Kim TY, Christensen JG, Oh DY, Bang YJ. Evaluation of the antitumor effects and mechanisms of PF00299804, a panHER inhibitor, alone or in combination with chemotherapy or targeted agents in gastric cancer. Mol Cancer Ther. 2012; 11:439-51.

56. Oh DY, Lee KW, Cho JY, Kang WK, Rha SY, Bang YJ. A phase II open-label trial of dacomitinibmonotherapy in patients with HER2-positive advanced gastric cancer after failure of at least one prior chemotherapy regimen. J Clin Oncol. 2012; (suppl 4; abstr 54).

57. Zhang B, Lahdenranta J, Du J, Kirouac D, Nguyen S, Overland R, Paragas V, Kudla A,Nielsen U, McDonagh C, Onsum M. MM-111, a bispecific HER2 and HER3 antibody,synergistically combines with trastuzumab and paclitaxel in preclinical models of gastriccancer. Proceedings of the 104th Annual Meeting of the American Association for Cancer Research; 2013 Apr 6-10; Washington, DC. Philadelphia (PA): AACR; Cancer Res 2013; 73:Abstract nr 4633

58. A Study of MM-111 and Paclitaxel With Trastuzumab in Patients HER2 Positive Carcinomas of the Distal Esophagus, Gastroesophageal (GE) Junction and Stomach. Available: https://clinicaltrials.gov/ct2/show/NCT0177485 1 ?term=NCT01774851\&rank=1 (accessed 08.06.2015).

59. Aprile G, Rihawi K, Scartozzi M, Bordonaro R. Steps ahead in the treatment of advanced colorectal cancer: past, current and possible future scenarios. Future Oncol. 2015; doi: 10.2217/fon.15.213

60. Venook AP, Niedzwiecki D, Lenz HJ, Innocenti F,
Mahoney MR, O'Neil BH, Shaw J, Polite B, Hochster H, Goldberg R, Mayer R, Schilsky R, Bertagnolli M, et al. CALGB/SWOG 80405: Phase III trial of irinotecan/5FU/leucovorin (FOLFIRI) or oxaliplatin/5-FU/leucovorin (mFOLFOX6) with bevacizumab (BV) or cetuximab (CET) for patients (pts) with KRAS wild-type (wt) untreated metastatic adenocarcinoma of the colon or rectum (MCRC). J Clin Oncol. 32:5s, 2014 (suppl; abstr LBA3).

61. Heinemann V, von Weikersthal LF, Decker T, Kiani A, Vehling-Kaiser U, Al-Batran SE, Heintges T, Lerchenmüller C, Kahl C, Seipelt G, Kullmann F, Stauch $\mathrm{M}$, Scheithauer W, et al. FOLFIRI plus cetuximab versus FOLFIRI plus bevacizumab as first-line treatment for patients with metastatic colorectal cancer (FIRE-3): a randomised, open-label, phase 3 trial. Lancet Oncol. 2014; 15:1065-75.

62. Loupakis F, Cremolini C, Masi G, Lonardi S, Zagonel V, Salvatore L, Cortesi E, Tomasello G, Ronzoni M, Spadi R, Zaniboni A, Tonini G, Buonadonna A,et al. Initial therapy with FOLFOXIRI and bevacizumab for metastatic colorectal cancer. N Engl J Med. 2014; 371:1609-18.

63. Grothey A, Van Cutsem E, Sobrero A, Siena S, Falcone A, Ychou M, Humblet Y, Bouché O, Mineur L, Barone C, Adenis A, Tabernero J, Yoshino T,et al. Regorafenib monotherapy for previously treated metastatic colorectal cancer (CORRECT): an international, multicentre, randomised, placebo-controlled, phase 3 trial. Lancet. 2013; 381:303-12.

64. Mayer RJ, Van Cutsem E, Falcone A, Yoshino T, GarciaCarbonero R, Mizunuma N, Yamazaki K, Shimada Y, Tabernero J, Komatsu Y, Sobrero A, Boucher E, Peeters $\mathrm{M}$,et al. Randomized trial of TAS-102 for refractory metastatic colorectal cancer. N Engl J Med. 2015; 372:1909-19.

65. Fakih MG. Metastatic Colorectal Cancer: Current State and Future Directions. J Clin Oncol. 2015; 33:1809-1824.

66. Blok EJ, Kuppen PJ, van Leeuwen JE, Sier CF. Cytoplasmic Overexpression of HER2: a Key Factor in Colorectal Cancer. Clin Med Insights Oncol. 2013; 7:41-51.

67. Lee WS, Park YH, Lee JN, Baek JH, Lee TH, Ha SY. Comparison of HER2 expression between primary colorectal cancer and their corresponding metastases. Cancer Med. 2014; 3:674-80.

68. Schuell B, Gruenberger T, Scheithauer W, Zielinski Ch, Wrba F. HER 2/neu protein expression in colorectal cancer. BMC Cancer. 2006; 6:123.

69. Ross JS, McKenna BJ. The HER-2/neu oncogene in tumors of the gastrointestinal tract. Cancer Invest. 2001; 19:554-68.

70. Farzand S, Siddique T, Saba K, Bukhari MH. Frequency of HER2/neu overexpression in adenocarcinoma of the gastrointestinal system. World J Gastroenterol. 2014; 20:5889-96.

71. Wollf AC, Hammond ME, Hicks DG, Dowsett M, McShane LM, Allison KH, Allred DC, Bartlett JM, Bilous 
M, Fitzgibbons P, Hanna W, Jenkins RB, Mangu PB, et al. Recommendations for human epidermal growth factor receptor 2 testing in breast cancer: American Society of Clinical Oncology/College of American Pathologists clinical practice guideline update. J ClinOncol. 2013; 31:3997-4013.

72. Ross JS, Slodkowska EA, Symmans WF, Pusztai L, Ravdin PM, Hortobagyi GN.The HER-2 receptor and breast cancer: ten years of targeted anti-HER-2 therapy and personalized medicine. Oncologist. 2009; 14:320-68.

73. NazemalhosseiniMojarad E, Kuppen PJ. HER2 and immunotherapy using monoclonal antibodies in colorectal cancer. Immunotherapy. 2013; 5:1267-9.

74. Seo AN, Kwak Y, Kim DW, Kang SB, Choe G, Kim WH, Lee HS. HER2 status in colorectal cancer: its clinical significance and the relationship between HER2 gene amplification and expression. PLoS One. 2014; 9:e98528.

75. Tu J, Yu Y, Liu W, Chen S. Significance of human epidermal growth factor receptor 2 expression in colorectal cancer. Exp Ther Med. 2015; 9:17-24.

76. Ingold Heppner B, Behrens HM, Balschun K, Haag J, Krüger S, Becker T, Röcken C. HER2/neu testing in primary colorectal carcinoma. Br J Cancer. 2014; 111:197784.

77. Song Z, Deng Y, Zhuang K, Li A, Liu S. Immunohistochemical results of HER2/neu protein expression assessed by rabbit monoclonal antibodies SP3 and 4B5 in colorectal carcinomas. Int J Clin Exp Pathol. 2014; 7:4454-60.

78. Sclafani F, Roy A, Cunningham D, Wotherspoon A, Peckitt C, Gonzalez de Castro D, Tabernero J, Glimelius B, Cervantes A, Eltahir Z, Oates J, Chau I. HER2 in high-risk rectal cancer patients treated in EXPERT-C, a randomized phase II trial of neoadjuvantcapecitabine and oxaliplatin (CAPOX) and chemoradiotherapy (CRT) with or without cetuximab. Ann Oncol. 2013; 24:3123-8.

79. Yonesaka K, Zejnullahu K, Okamoto I, Satoh T, Cappuzzo F, Souglakos J, Ercan D, Rogers A, Roncalli M, Takeda M, Fujisaka Y, Philips J, Shimizu T,et al. Activation of ERBB2 signaling causes resistance to the EGFR-directed therapeutic antibody cetuximab. Sci Transl Med. 2011; 3:99ra86.

80. Cancer Genome Atlas Network. Comprehensive molecular characterization of human colon and rectal cancer. Nature 2012; 487:330-7.

81. Bose R, Kavuri SM, Searleman AC, Shen W, Shen D, Koboldt DC, Monsey J, Goel N, Aronson AB, Li S, Ma CX, Ding L, Mardis ER,et al. Activating HER2 mutations in HER2 gene amplification negativebreast cancer. Cancer Discov 2013; 3:224-37.

82. GreulichH, Kaplan B, Mertins P, Chen TH, Tanaka KE, Yun $\mathrm{CH}$, Zhang X, Lee SH, Cho J, Ambrogio L, Liao R, Imielinski M, Banerji S,et al. Functional analysis of receptor tyrosine kinase mutations in lung cancer identifies oncogenic extracellular domain mutations of ERBB2. Proc Natl Acad Sci USA. 2012; 109:14476-81.

83. Kavuri SM, Jain N, Galimi F, Cottino F, Leto SM, Migliardi G, Searleman AC, Shen W, Monsey J, Trusolino L, Jacobs SA, Bertotti A, Bose R. HER2 activating mutations are targets for colorectal cancer treatment. Cancer Discov. 2015; 5:832-41.

84. Leto SM, Sassi F, Catalano I,Torri V, Migliardi G, Zanella ER, Throsby M, Bertotti A, Trusolino L.Sustained inhibition of HER3 and EGFR is necessary to induce regression of HER2-amplified gastrointestinal carcinomas. Clin Cancer Res. 2015; pii: clincanres.3066.2014. doi: 10.1158/1078-0432.CCR-14-3066.

85. Pectasides E, Bass AJ. ERBB2 emerges as a new target for colorectal cancer. Cancer Discov. 2015; 5:799-801.

86. Missiaglia E, Jacobs B, D'Ario G, Di Narzo AF, Soneson C, Budinska E, Popovici V, Vecchione L, Gerster S, Yan P, Roth AD, Klingbiel D, Bosman FT, et al. Distal and proximal colon cancers differ in terms of molecular, pathological, and clinical features. Ann Oncol. 2014; 25:1995-2001.

87. Aprile G, De Maglio G, Menis J, Casagrande M, Tuniz F, Pisa EF, Fontanella C, Skrap M, Beltrami AC, Fasola G, Pizzolitto S.HER-2 Expression in Brain Metastases from Colorectal Cancer and Corresponding Primary Tumors: A Case Cohort Series. Int J Mol Sci. 2013; 14:2370-87.

88. Chen J, Li Q, Wang C, Wu J, Zhao G. Prognostic significance of c-erbB-2 and vascular endothelial growth factor in colorectal liver metastases. Ann Surg Oncol. 2010; 17:1555-63.

89. Ramanathan RK, Hwang JJ, Zamboni WC, Sinicrope FA, Safran H, Wong MK, Earle M, Brufsky A, Evans T, Troetschel M, Walko C, Day R, Chen HX, et al. Low overexpression of HER-2/neu in advanced colorectal cancer limits the usefulness of trastuzumab (Herceptin) and irinotecan as therapy. A phase II trial. Cancer Invest. 2004; 22:858-65.

90. Clark J, Niedzwiecki D, Hollis D, Mayer R. Phase II trial of 5-fluororuacil (5-FU), leucovorin (LV), oxaliplatin (Ox), and trastuzumab $(\mathrm{T})$ for patients with metastatic colorectal cancer (CRC) refractory to initial therapy. Proc Am Soc Clin Oncol. 2003, 22:abstr 3584.

91. Frank D, Jumonville A, Loconte NK, Schelman WR, Mulkerin D, Lubner S, Richter K, Winterle N, Wims MB, Dietrich L, Winkler JM, Volk M, Kim K, et al. A phase II study of capecitabine and lapatinib in advanced refractory colorectal adenocarcinoma: A Wisconsin Oncology Network study. J Gastrointest Oncol. 2012; 3:90-6.

92. LaBonte MJ, Wilson PM, Fazzone W, Russell J, Louie SG, El-Khoueiry A, Lenz HJ, Ladner RD. The dual EGFR/HER2 inhibitor lapatinib synergistically enhances the antitumor activity of the histone deacetylase inhibitor panobinostat in colorectal cancer models. Cancer Res. 2011; 71:3635-48. 
93. Rubinson DA, Hochster HS, Ryan DP, WolpinBM, McCleary NJ, Abrams TA, Chan JA, Iqbal S, Lenz HJ, Lim D, Rose J, Bekaii-Saab T, Chen HX, et al. Multi-drug inhibition of the HER pathway in metastatic colorectal cancer: results of a phase I study of pertuzumab plus cetuximab in cetuximab-refractory patients. Invest New Drugs. 2014; 32:113-22.

94. Valtorta E, Martino C, Sartore-Bianchi A, Penaullt-Llorca F, Viale G, Risio M, Rugge M, Grigioni W, Bencardino K, Lonardi S, Zagonel V, Leone F, Noe J, et al. Assessment of a HER2 scoring system for colorectal cancer: results from a validation study. Mod Pathol. 2015; 28:1481-91. doi: 10.1038/modpathol.2015.98.

95. Sartore-Bianchi A, Trusolino L, Martino C, Bencardino K, Lonardi S, Bergamo F, Zagonel V, Leone F, Depetris I, Martinelli E, Troiani T, Ciardiello F, Racca P, et al. Dual-targeted therapy with trastuzumab and lapatinib in treatment-refractory, KRAS codon 12/13 wild-type, HER2-positive metastatic colorectal cancer (HERACLES): a proof-of-concept, multicentre, open-label, phase 2 trial. Lancet Oncol. 2016; pii: S1470-2045(16)00150-9. doi: 10.1016/S1470-2045(16)00150-9
96. Ahmed N, Brawley VS, Hegde M, Robertson C, Ghazi A, Gerken C, Liu E, Dakhova O, Ashoori A, Corder A, Gray T, Wu MF, Liu H, et al. Human Epidermal Growth Factor Receptor 2 (HER2) -Specific Chimeric Antigen ReceptorModified T Cells for the Immunotherapy of HER2-Positive Sarcoma. J Clin Oncol. 2015; 33:1688-96.

97. Pribluda A, de la Cruz CC, Jackson EL. Intratumoral Heterogeneity: From Diversity Comes Resistance. Clin Cancer Res. 2015; 21:2916-23. 